Prace Komisji Geografii Komunikacji PTG

Transport Geography Papers of Polish Gegraphicl Socis

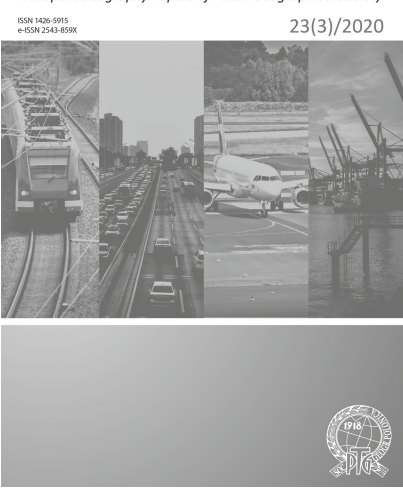

Transport Geography Papers of Polish Geographical Society

$2020,23(3), 61-68$

DOI 10.4467/2543859XPKG.20.020.12788
Received (Otrzymano): 08.05.2020

Received in revised form (Otrzymano poprawioną wersję): 20.06.2020

Accepted (Zaakceptowano): 20.06.2020

Published (Opublikowano): 30.06.2020

\title{
CONCEPT OF GREEN PORTS. CASE STUDY OF THE SEAPORT IN GDYNIA
}

\section{Koncepcja Zielonych Portów. Przypadek portu morskiego w Gdyni}

\author{
Sandra Żukowska \\ Division of Regional Development, Faculty of Oceanography and Geography, University of Gdańsk, J. Bażyńskiego 4, 80-309 Gdańsk, Poland \\ e-mail: sandrazukowska01@gmail.com
}

\section{Citation:}

Żukowska S., 2020, Concept of green seaports. Case study of the seaport in Gdynia, Prace Komisji Geografii Komunikacji PTG, 23(3), 61-68.

Abstract: World transport faces a serious challenge, which involves the detrimental impact of its activity on the environment. Marine transport is a significant link in the worldwide transport system, which provides the free flow of diversified cargoes and offers competitive prices compared to other modes of transport for the carriage of goods. Seaports enabling waterborne transport have a major impact on the economic, social and natural environment. Port managing authorities show growing awareness of the negative influence of port units on the surrounding environment. Concurrently, environmentally friendly measures are implemented in line with the principles of sustainable development. The article aim is to present the characteristics of the green ports concept in response to ports struggle with environmental problems. The article presents port development background and the evolving approach to environmental issues. The seaport in Gdynia is an example of pursuing a sustainable development policy, and informally is well embedded in the concept of green ports.

Key terms: marine transport, seaport, green ports, sustainable development 


\section{Introduction}

Seaports are called the catalysers of social, economic and spatial development of a given region. They embrace transport, industrial, trade, logistics and distribution functions and in terms of spatial development are 'city-genic' and 'region-genic' (Montwiłł, 2011). Traditionally, seaports mean land and water adjacent areas equipped with facilities for providing port services (Misztal et al., 1988). These include the infrastructure (port water basins, port premises, transport system, networks and nodes) and port suprastructure (cargo handling equipment, port rolling stock, warehouses, storage yards, and other equipment and auxiliary facilities). Seaports are subject to continuous evolution resulting from economic transformation and global trends. The changes in the social sphere and the evolving approach to comprehensive protection and responsibility for the environment also play a significant role.

The objective of the study is to develop a synthetic characteristic of the concept of green ports in response to environmental problems in the maritime sector. It will refer to development basics and the evolution of ports' approach to environmental issues. The study is based on a review of national and international papers about the range of environmental trends in port development and environmental issues.

\section{Seaport generations}

The report of the United Nations Conference on Trade Development ${ }^{1}$ identifies three basic port generations in the effort to develop a synthetic overview and define development stages. The division into tangible generation types is based on the following categories: type of cargo handled, strategies, scope of operations, operation characteristics, interfaces and dominating factors. The article presents a specific division into generations in three time spans (up to 1960 , after 1960 and following 1980).

- Up to 1960, Generation I ports dominated. They predominantly provided the simple handling of semi bulk cargo. This type of port was an independent and isolated entity, which failed to maintain relations with the surrounding environment.

- After 1960, ports experienced a clear development phase, conditioned by the principles of competitiveness and rivalry between particular

\footnotetext{
Report by the UNCTAD Secretariat, 1992, Port marketing and the challenge of the third generation port, https:// unctad.org/en/PublicationsLibrary/tdc4ac7_d14_en.pdf [20.04.2020].
}

entities (Montwiłł, 2011). Bulk cargo (in particular oil and derivatives) characterised the cargo structure. Generation II ports opened up to economic relations and interfaces evolving into service and transport complexes. The growing cargo handling operations (connected with containerisation), functional and spatial development of ports augmented the risks for the environment.

- The transition from Generation II to Generation III ports (after 1980) was related to transformation of administrative issues and changing attitude to the surrounding environment. Port efficacy influenced their dominating nature and competitiveness compared to earlier Generation ports. The rising trend in port handling volumes resulted in ports developing their hinterland with logistics distribution hubs. They comprised an integrated system and logistic platform for international trade turnover. Port operations meant diversification of services beyond the earlier port principal functions. Cargo groups handled by Generation III ports comprised bulk cargo, general cargo and containers. The development of relations and building closer relations between the port and the city structure gained weight.

Apart from the three main generations, professional literature also indicates further generations, These are: Generations IV, V and VI.

Generation IV ports feature a cross-regional nature, developed cooperation of ports' authorities and the development of a common administrating unit (UNCTAD secretariat, 1999). The involvement of the private sector in investment related decision-making is clearly visible. J. Semenov (2003) pointed out to the transformation of the port sector noting the lack of methodology in identifying the grounds for the development of Generation IV ports. Their initially characteristic feature, compared to earlier generations, was their attitude to adapt and comply with safety requirements in their operation.

M. Flynn, P. Lee and T. Notteboom noted that the next generation of ports must demonstrate major actions regarding relations between the port and its stakeholders, which include local society, economic entities, local, regional and national self-governments and others (Flynn et al., 2011). Generation $\checkmark$ ports should maintain close relations with local society in solving problems and conflicts resulting from port activity. Port strategies should focus on sustainable development of both the foreground and the hinterland. The strategies would augment the quality of logistics and uninterrupted cargo flow. Environmentally friendly port actions are also among these major measures. These include reduction of exhaust emission, mitigating hazards related to port 
operations, education and sharing knowledge (Kaliszewski, 2017).

Professional literature also points to Generation VI ports. Their distinguishing feature would be handling 50 thousand TEU container vessels with a draught of over 20 meters. Comprehensive automation ${ }^{2}$ of port processes is projected as their operational basis with comprehensive handling of intermodal connections and low external costs. Generation VI ports would be bound to modernise their infrastructure, among others, to expand premises for storing goods, to implement new technologies to manage goods in port yards and use gantry cranes adapted to the new cargo handling reality (Kaliszewski, 2017). This Generation meets with criticism due to generated costs remaining disproportional to potential benefits.

\section{Environmental impact of seaports}

Seaports, apart from their positive input to economic development, have their significant negative impact on the operational premises, the urban environment, the natural environment - on land and water. The progressive development of ports will generate a growing threat to the natural environment. Thus, the fundamentals for further growth mean that ports should account for sustainability in their development and their expansion policies. The pollution sources in seaports can be divided into two main groups:

- those related to the presence of ships, other waterborne crafts and cargo, and

- those related to the hinterland and investment measures.

Ships in port emit harmful gasses and dusts to the atmosphere. They also pollute water and soil. The basic explanations for the pollution include ship bunkering and possible collisions of waterborne units. In the case of cargo, the handling activity in port creates a hazard particularly when handling hazardous cargo (inter alia chemical substances) and operations related to their storage and warehousing. Another source of pollution originates in services and production operations as well as port development and investments (dredging approach fairways and the internal water basins, waste disposal). The linkage of port with the hinterland generates noise, vibrations,

An example of a fully automated port facility is the unmanned port Yangshan in Shanghai. Growing cargo handling effectiveness of ports involve application of intelligent solutions, among others, autonomic vehicles, which ensure collision free transport of cargo (Shanghai opened the biggest..., 2018) congestion and potential collisions and transport accidents (Klopott, 2013). The emission of carbon dioxide $\left(\mathrm{CO}_{2}\right)$, sulphur oxides $\left(\mathrm{SO}_{2}\right)$, and nitrogen oxides $\left(\mathrm{NO}_{2}\right)$ have a key impact on climate changes and the greenhouse effect.

The attitude of ports to their surroundings in terms of environmental priorities have changed. The evolving approach to environmental issues in the years 1996-2019 is presented in the environmental report ESPO 2019, which was published on the EcoPorts website ${ }^{3}$. EcoPorts is the effect of the proactive environment initiative undertaken by the European port sector widely collaborating and sharing knowledge about the environment (ecoports.com) (tab. 1).

Air quality is a key priority aspect. The issue remains in the lead of port environmental priorities. Port activity shows a distinctive impact on deteriorating air quality in port vicinity, in this case the municipal neighbourhood, as $90 \%$ of European ports operate in municipal areas (ecoports.com). Air pollution of anthropogenic origin generates considerable social costs (high mortality rate caused by tumours, strokes and cardiac diseases). Since 2016 power consumption has ranked second after air quality. This aspect is substantially related with port effectiveness and the impact on power related costs as well as the shift to green energy. Climate changes appeared for the first time as the last item of priorities in 2017. This leads to a meaningful shift as in the 2019 priority set climate change ranked third after air quality and energy consumption in three particularly important priorities for European ports (ESPO, 2019). The data referred to above indicates a rising trend in respecting climate related regulations, a shift to low emission operations and a reduction of ports detrimental impact on the environment. The three aspects constitute in their present reading the foundations of the environmental priorities of the port sector. The next item is the question of noise generated by port operations. The 2009 priorities pointed to noise as the key problem. With time, noise has lost its position to air quality and energy consumption. Relations with local society are another element. Ports are beginning to acknowledge the building potency of cooperation and strengthened relations with neighbouring society and no longer form closed enclaves in a municipal environment. The next priorities embrace ship waste and waste generated by port activity. Port operations involve collection, storage and safe treatment of waste. The remaining three items cover port land related development and seabed related port operations (dredging of port basins). Water quality is at the end of the list maintained for the last 23 years.

EcoPorts, https://www.ecoports.com [21.04.2020]. 
Tab. 1. Changing environmental priorities of European ports.

\begin{tabular}{|c|c|c|c|c|c|c|c|}
\hline 1996 & 2004 & 2009 & 2013 & 2016 & 2017 & 2018 & 2019 \\
\hline $\begin{array}{c}\text { Port } \\
\text { development } \\
\text { (water) }\end{array}$ & $\begin{array}{c}\text { Garbage / port } \\
\text { waste }\end{array}$ & Noise & Air quality & Air quality & Air quality & Air quality & Air quality \\
\hline Water quality & $\begin{array}{l}\text { Dredging } \\
\text { operations }\end{array}$ & Air quality & $\begin{array}{c}\text { Garbage / port } \\
\text { waste }\end{array}$ & $\begin{array}{c}\text { Power } \\
\text { consumption }\end{array}$ & $\begin{array}{c}\text { Power } \\
\text { consumption }\end{array}$ & $\begin{array}{c}\text { Power } \\
\text { consumption }\end{array}$ & $\begin{array}{c}\text { Power } \\
\text { consumption }\end{array}$ \\
\hline $\begin{array}{l}\text { Dredging } \\
\text { disposal }\end{array}$ & $\begin{array}{l}\text { Dredging } \\
\text { disposal }\end{array}$ & $\begin{array}{c}\text { Garbage / port } \\
\text { waste }\end{array}$ & $\begin{array}{c}\text { Power } \\
\text { consumption }\end{array}$ & Noise & Noise & Noise & $\begin{array}{l}\text { Climate } \\
\text { change }\end{array}$ \\
\hline $\begin{array}{l}\text { Dredging } \\
\text { operations }\end{array}$ & Dust & $\begin{array}{l}\text { Dredging } \\
\text { operations }\end{array}$ & Noise & $\begin{array}{l}\text { Relationship } \\
\text { with local } \\
\text { community }\end{array}$ & Water quality & $\begin{array}{l}\text { Relationship } \\
\text { with local } \\
\text { community }\end{array}$ & Noise \\
\hline Dust & Noise & $\begin{array}{l}\text { Dredging } \\
\text { disposal }\end{array}$ & Ship waste & $\begin{array}{c}\text { Garbage / port } \\
\text { waste }\end{array}$ & $\begin{array}{l}\text { Dredging } \\
\text { operations }\end{array}$ & Ship waste & $\begin{array}{l}\text { Relationship } \\
\text { with local } \\
\text { community }\end{array}$ \\
\hline $\begin{array}{c}\text { Port } \\
\text { development } \\
\text { (land related) }\end{array}$ & Air quality & $\begin{array}{l}\text { Relationship } \\
\text { with local } \\
\text { community }\end{array}$ & $\begin{array}{l}\text { Relationship } \\
\text { with local } \\
\text { community }\end{array}$ & Ship waste & $\begin{array}{c}\text { Garbage / port } \\
\text { waste }\end{array}$ & $\begin{array}{c}\text { Port } \\
\text { development } \\
\text { (land related) }\end{array}$ & Ship waste \\
\hline $\begin{array}{l}\text { Contaminated } \\
\text { land }\end{array}$ & $\begin{array}{l}\text { Hazardous } \\
\text { cargo }\end{array}$ & $\begin{array}{c}\text { Power } \\
\text { consumption }\end{array}$ & $\begin{array}{l}\text { Dredging } \\
\text { operations }\end{array}$ & $\begin{array}{c}\text { Port } \\
\text { development } \\
\text { (land related) }\end{array}$ & $\begin{array}{c}\text { Port } \\
\text { development } \\
\text { (land related) }\end{array}$ & $\begin{array}{l}\text { Climate } \\
\text { change }\end{array}$ & $\begin{array}{c}\text { Garbage / port } \\
\text { waste }\end{array}$ \\
\hline $\begin{array}{l}\text { Habitat loss/ } \\
\text { degradation }\end{array}$ & Bunkering & Dust & Dust & Water quality & $\begin{array}{l}\text { Relationship } \\
\text { with local } \\
\text { community }\end{array}$ & Water quality & $\begin{array}{c}\text { Port } \\
\text { development } \\
\text { (land related) }\end{array}$ \\
\hline Traffic volume & $\begin{array}{c}\text { Port } \\
\text { development } \\
\text { (land related) }\end{array}$ & $\begin{array}{c}\text { Port } \\
\text { development } \\
\text { (water) }\end{array}$ & $\begin{array}{c}\text { Port } \\
\text { development } \\
\text { (land related) }\end{array}$ & Dust & Ship waste & $\begin{array}{l}\text { Dredging } \\
\text { operations }\end{array}$ & $\begin{array}{l}\text { Dredging } \\
\text { operations }\end{array}$ \\
\hline $\begin{array}{l}\text { Industrial } \\
\text { effluent }\end{array}$ & $\begin{array}{l}\text { Ship discharge } \\
\text { (bilge) }\end{array}$ & $\begin{array}{c}\text { Port } \\
\text { development } \\
\text { (land related) }\end{array}$ & Water quality & $\begin{array}{l}\text { Dredging } \\
\text { operations }\end{array}$ & $\begin{array}{l}\text { Climate } \\
\text { change }\end{array}$ & $\begin{array}{c}\text { Garbage / port } \\
\text { waste }\end{array}$ & Water quality \\
\hline
\end{tabular}

Source: ESPO Environmental Report 2019, Table 7, p. 12.

\section{Concept of green ports}

This section, referring to the environmental impact of seaports, outlines the costs side of the issue. Costs are borne by ports and the city (society) in result of ports' detrimental environmental impact. In the case of ports, these are private port costs resulting from their operation, whereas external costs burden the society, which functions in the port-municipality unit (Grzelakowski, 2011). Environmentally friendly initiatives are crucial in mitigating the negative footprint of ports on the environment and require a multi-aspect and long-term sustainable approach to environmental issues. Such measures would lower external costs (Klopott, 2012). Ecology related pressure on port entities grows with the proximity of ports to human clusters and nature areas susceptible to anthropogenic influence. The creation of an eco-positive ${ }^{4}$ port image

$4 \quad$ Building an ecopositive image by ports is an important measure, which illustrates the environment awareness level. It refers to creating a competitive edge, improving relations and building synergy between the port and the city. These goals are achieved by instigating steps, which limit the influence of ports on the environment in which it operates by, inter alia, implementing and popularising environmentally friendly solutions in transport. is of fundamental significance and contributes to rising port competitiveness.

Environmental initiatives should involve three main elements; i.e. the environment, economy and society. The response to key problems is the socalled green port, which takes into account these elements and ranks them as crucial in its operational activity. Green ports are the effect of study initiatives undertaken by scientific circles and the sector communities specialising in development policies of the marine sector (Lawer et al., 2019). Initially, the term "green port" identified a new ideology of sustainable development of the port sector and referred solely to ports themselves, which balanced their environmental footprint by economic benefits. The year 2010 marks a new, wider approach to the concept of green ports as an agent and concurrently a growth centre. Its mission is to establish a development plane allowing for its basic operations in full harmony with environmental and social aspects. The term "green port" has been used in Anglo-Saxon literature since the nineties of the twentieth century. According to A. Martiz, C.J.Shieh and S. P. Yeh (2014), green ports show a global trend in response to the energy crisis and the deteriorating state of the natural environment. The authors point out that port manage- 
ment systems should aim at maintaining a balance between environmental protection and economic objectives. Green ports characterizes rational use of resources, effective implementation of environmental protection policies, reduction of energy consumption, and demonstrate social responsibility (A. Martiz et al., 2014). The subject of green ports in polish literature is at the exploratory stage, nonetheless the deliberations of A.S. Grzelakowski (2011) should be duly noted. These refer to export as a new direction and form of European port development and environmental governance in maritime economy.

In order to structure the terminology, the following two basic definitions have been chosen:

- Green ports - meaning ports that apply development and investment measures to mitigate the negative impact of port operations and to improve environmental conditions. The strategic aspect covers long-term and sustainable actions aimed at continuous growth of port functionality concurrently improving social and environmental aspects. They embrace the economic, social and environmental spheres. Augmented effectiveness in managing the work environment, maximising the use of own resources and improved quality of the surrounding environment constitute a significant aspect of the strategy. They also form a special component of the public private cooperation sector towards initiatives on environmental protection and raising environmental awareness. A synonym term would be "ports of sustainable development" and "ecological ports" (A. Oniszczuk-Jastrząbek et al., 2018).

- Ecoports - meaning ports, which implement the concept of internalising external costs ${ }^{5}$. They facilitate the solving of environmental problems drawing on the opportunities of the diversified port services market. According to A.S. Grzelakowski (2011, p. 15) these include 'autonomic mechanisms for choosing products, relying on a price system based on border costs (SMCP)'.

The common feature of both is a long-term vision, commitment and comprehensive strategy of the port to ensure low emission and to create partnership relations with the surrounding environment.

The concept basis on sustainable development. Accordingly, three main rules are specified such as polluter pays, which concerns paying for polluting, and user pays, which implies the duty to pay for the use of infrastructure and thus generates an income which can be used to modernise the infrastructure. The rule of full coverage of costs for using the infrastructure refers to final prices for their use, including social costs (A.S. Grzelakowski, 2011).

\section{Case study of the seaport in Gdynia}

None of the Polish ports joined the EcoPort initiative as the overall European forum of environmentally friendly actions and knowledge transfer. Gdynia Port Authorities (Zarząd Morskiego Portu Gdynia S.A.) has adopted a special pro-ecological attitude and a sustainable development policy. The seaport in Gdynia, located at outlet of the Kashubian Urstromtal to the waters of Gdańsk Bay, is outstanding compared to other ports. This outstanding feature is the city forming nature of the port and fundamental meaning for the functioning and growth of the Gdynia port municipal unit. In the traditional approach, the port grows with the city. In the case of Gdynia, the port was decisive for the development of the municipal structure around its borders (the city spreads around the port), thus the city grew together with the port.

Seaports undertaking environmentally friendly actions start formalising actions by gaining certificates. These confirm the implementation of management systems based on specified standards (Klopott, 2013). In the case of Gdynia port, four main certificates need mentioning. These are the ISO 14001, ISO 9001, ISO 45001 and ISO 22000 certificates. The most popular environmental standard is ISO 14001. The standard governs environmental management aimed predominantly at mitigating the negative impact of the entity on the environment and environment protection. Apart from port environment oriented own actions on environmental management, standards foresee compliance with legal requirements and regulations regarding environmental protection. The other certifications refer to quality management systems (ISO 9001), and in particular to improving relations with stakeholders and the improved quality of services rendered. ISO 45001 covers the occupational health and safety management system $(\mathrm{OH} \& S)$, which shapes the awareness and responsibility to ensure labour safety and culture. ISO 22000 HCCP deals with food safety management.

The Strategy for the development of Gdynia Port up to 2027 was adopted in 2014, and responds to the present technological, environmental and economic challenges. The development strategy is a document which outlines the key trends in port development. The main issue is to ensure keeping its universal character. The key mission of the port is sustainable development and ensured partnership relations with the social environment. It is necessary to develop the most effective standards in pro-ecological measures and safety (Gdynia Port Authorities S.A.). The priorities listed in the port strategic document refer to four segments: maintaining the universal character of the 
port, modern potential, transport accessibility and port friendly for the surrounding environment. The steps undertaken by the port comply with the concept of a green port and cover three areas: economy, environment and society (Gdynia Port Authorities S.A.). These embrace:

- Close economic relations with the hinterland,

- More effective and sustainable use of the natural potential of resources and assets of Gdynia port,

- Enhanced competitive position on the European market by conducting comprehensive modernisation and investments in port infrastructure (handling and storage), parameters and throughput (Gdynia Port Authorities S.A.).

Among the special pro-ecologic actions of the port we can distinguish:

- Engagement in the development of green energy sources (wind farms) and the development of the offshore sector (Biniek, 2017). Gdynia port is to take on the role of the basic operator in the governmental green initiatives with reference to cargo handling and completing wind farm sets and their transport to target locations on the Baltic Sea. Port Authorities shall dedicate areas in the external port premises to implement the green initiative. The initiative shall influence energy transformation in the country and growing importance of green energy (Gdynia Port Authorities S.A.).

- Partnership under the European Water Innovation System Amplifier (WISA) initiative: test-beds for water innovation (Water Innovation System Amplifier) ${ }^{6}$. The initiative assumes undertaking steps to limit pollution of waters flowing to the Baltic Sea (together with rainwater and waste waters). The initiative will create a forum of knowledge and exchange of experience with other Baltic ports participating in the project (Gdynia Port Authorities S.A.).

- Gdynia port is introducing bunkering of ecologic fuel LNG. The use of alternative fuels in port is a step forward in implementing the concept of green ports, it minimises air emission compared to traditional fuels and reduces fuel storage and transport costs ('Fuel of the future' in Gdynia port, 2019).

- The port is equipped with facilities for measuring air pollution (dust PM2.5 and PM10) ${ }^{7}$. The measuring points are located in the southern part of the

6 WISA - Water Innovation System Amplifier, https://southbaltic.eu/-/wisa [22.04.2020].

7 PM2.5 and PM10 dusts are atmospheric aerosols and mixtures of dangerous particles, which generate a special hazard to human life and health. port, in close vicinity to urban tissue. Monitoring is to provide a potential measure to eliminate hazardous dust in cargo handling processes (Gdynia Port Authorities S.A.).

- The state of the seabed sediments in port basins is regularly tested as projected in $\mathrm{HELCOM}^{8}$ guidelines. The port measures the content of metals (arsenic, chrome, zinc, copper, nickel, lead, mercury), $\mathrm{PAH}^{9}$, among them benzopirazine and polychlorinated biphenyls, (PCBs).

- Monitoring, physical and chemical testing of the so-called offshore dumping sites and adjacent areas. The dumping sites are dedicated locations at sea for the spoil excavated in the process of dredging port basins. Measurements are carried out every three years at average. The objective is to check whether the deposited sediment produced in the dredging process leaves a detrimental footprint on sea bottom habitats in the dump site vicinity and its impact on Natura 2000 protected areas Gdańsk Bay and Hel Peninsula).

- The port tests the quality of seawater in 28 marked measuring spots on the premises of the entire port to identify the contamination level. Rational management of rainwater by managing entities has an important impact on port water quality. An upgraded rainwater system equipped with pre-treatment facilities is responsible for limiting the negative impact. The testing of the quality of underground waters takes place twice a year (one in the western part of the port and three in the southern part) to identify anthropogenic influence on the bottom, middle and top water tables (Gdynia Port Authorities S.A.).

- Strict supervision is coordinated and focuses on ensuring the cleanliness of port basins and the outer harbour, and fast response to pollution (oil spills, algae blooming, navigation obstacles, dangerous waste - oil derivatives. The port has an integrated system for combating threats and pollution of port water jointly with external entities (Plan for combating..., 2016).

- The noise level caused by port operations is measured as well as noise originating from transport units (Gdynia Port Authorities S.A.).

- The soil quality is tested and the land-water conditions on the port premises (Gdynia Port Authorities S.A.).

- In 2018, the waste management plan and management plan for dealing with cargo residue from

HELCOM (Baltic Marine Environment Protection Commission - Helsinki Commission) https://helcom.fi [22.04.2020].

9 Polycyclic aromatic hydrocarbon (PAH). 
ships were updated and specify a comprehensive range of regulations and procedures (Port plan for management..., 2018). Port infrastructure for collection of waste from ships was constructed, and in particular facilities for sanitary waste, a retention tank, pumping station and installation for waste waters treatment from ships.

- Gdynia port cooperates with the social and economic environment (scientific centres, institutions), which conduct development studies involving cooperation, internships, study projects, training.

- The port instigated an action 'let's share the goodness' to aid the local society and neighbouring communes (pol. gmina) in face of the SARS-CoV-2 pandemic and acquired four specialist instruments for diagnosing the virus infection. The instruments were forwarded to the hospitals in the cities and towns of Gdynia, Gdańsk, Wejherowo and Kościerzyna. The instruments, apart from diagnosing SARS-CoV-2, will also serve other laboratory objectives.

\section{Conclusions}

The negative impact of seaports on the environment is an inseparable effect of port operations. The above study shows that the development of ports, and their upgrade from a lower to a higher port generation, exhibit port growth both in care for the hinterland and the resultant effectiveness. Growing awareness of this phenomenon is illustrated by the environmental priorities presented in the article. The studied data indicate the growing commitment to priorities in port operations related to air pollution, climate changes, energy consumption, generated noise and relations with society.

Gdynia port demonstrates an active environmental policy and numerous initiatives aimed at mitigating its negative impact. These actions include active participation in European partnership initiatives on reducing pollutant volumes entering inland waters. The port monitors harmful particulate matter content in the air and regularly tests the quality of water and soil on the port premises. Control measurements are also carried out beyond the port borders and cover dumping sites for depositing dredging spoil. The implementation of LNG bunkering facilities for ecological fuel as an alternative to traditional fuel is another key operational aspect. These measures fit well to the concept of green ports though the port is not officially present among European ports cooperating under the EcoPorts initiative. Green ports not only 'favour the environment', but also make efforts towards energy transformation and the use of green energy. Gdynia port is engaged in the development of the offshore sector and is to take on the role of the main operator in handling, completing and transporting construction components of wind farms. We cannot pass over the social activity of the port. As the study shows, an example of a social measure is, among others, the purchase of special instruments for hospitals to aid diagnosing diseases threatening the health and life of the population. This exemplifies the strengthening of port-city relations.

\section{Literature}

Biniek P., 2017, Perspektywy rozwoju sektora offshore w Polsce na przykładzie morskiej energetyki wiatrowej - wybrane problemy sektora transportu, Prace Komisji Geografii Komunikacji PTG, 20(3), pp. 44-52. (DOI 10.44 67/2543859XPKG.17.015.7489)

EcoPorts, https://www.ecoports.com [access 21.04.2020].

ESPO Environmental Report 2019, https://www.espo.be/ media/Environmental\%20Report-2019\%20FINAL.pdf [access 20.04.2020].

Flynn M., Lee P., Notteboom T., 2011, The next step on the port generations ladder: Customer-centric and community ports, [in:] boom (ed.), T. Notteboom, Current Issues in Shipping, Ports and Logistics, University Press Antwerp, Brussels, pp. 497-510.

Grzelakowski A. S., 2011, Ekoporty jako nowy kierunek i forma rozwoju portów morskich w Unii Europejskiej oraz kreowania ładu ekologicznego w tym sektorze gospodarki, Zeszyty Naukowe Uniwersytetu Szczecińskiego, (15), Szczecin, pp. 11-25.

HELCOM (Baltic Marine Environment Protection Commission - Helsinki Commission) https://helcom.fi [access 22.04.2020].

Kaliszewski A., 2017, Porty piątej oraz szóstej generacji (5GP, 6GP) - ewolucja ekonomicznej i społecznej roli portów, Studia I Materiały Instytutu Transportu i Handlu Morskiego, (14), pp. 93-123.

Klopott M., 2010, Zarządzanie środowiskowe w portach morskich Europy, Czasopismo Logistyka, (6) pp. 1-9.

Klopott M., 2012, Proekologiczne inicjatywy w portach morskich na rzecz zrównoważonego rozwoju, Zeszyty Naukowe Uniwersytetu Szczecińskiego, (18), pp. 113-125.

Lawer E. T., Herbeck J., Flitner M., 2019, Selective Adoption: How Port Authorities in Europe and West Africa Engage with the Globalizing "Green Port" Idea, Sustainability, Vol. 11(18), pp. 1-22.

Martiz A., Shieh C.J., Yeh S.P., 2014, Innovation and success factors in the construction of green ports, Journal of Environmental Protection and Ecology, 15, pp. 1255-1263.

Misztal K., Kuźma L., Grzelakowski A., 1988, Organizacja i eksploatacja portów morskich, Wydawnictwo Uniwersytetu Gdańskiego, Gdańsk. 
Montwiłł A., 2011, Generacje portów morskich a rozwój funkcji logistyczno-dystrybucyjnej, Czasopismo Logistyka, (1), pp. 16-19.

Oniszczuk-Jastrząbek A., Pawłowska B, Czermański E., 2018, Polish seaports and the Green Port concept, SHS Web of Conferences, 57, InfoGlob, pp. 2-11.

„Paliwo przyszłości” w gdyńskim porcie, 2019, Gdynia.pl, https://www.gdynia.pl/co-nowego,2774/paliwo-przyszlosci-w-gdynskim-porcie,535430 [access: 21.04.2020].

Plan zwalczania zagrożeń i zanieczyszczeń wód portowych, 2016, https://www.port.gdynia.pl/files/ochrona/ zwalczanie_zagrozen/zagrozenia_s_old.pdf [access 21.04.2020].

Portowy plan gospodarowania odpadami oraz pozostałościami ładunkowymi ze statków w Porcie Gdynia, 2018, https://www.port.gdynia.pl/files/ochrona/odpady_statkowe/2018_AKTUALIZACJA\%20PLANU\%20-\%20wersja\%20ostateczna.pdf [access 21.04.2020].

Report by the UNCTAD Secretariat, 1992, Port marketing and the challenge of the third generation port, htt-
ps://unctad.org/en/PublicationsLibrary/tdc4ac7_d14_ en.pdf [access 20.04.2020].

Semenov J., 2003, Kierunki strategiczne podwyższenia konkurencyjności polskich portów na tle wymogów UE, [w:] red. K. Chwesiuk, Konkurencyjność polskich portów morskich w świetle integracji z Uniq Europejskq, Wydawnictwo Kreos, Szczecin, pp. 1-13.

Szanghajotworzyłnajwiększyna świecie „portbezzałogowy”, 2018, http://polish.cri.cn/1364/2018/09/17/27s141228. htm [access 21.04.2020].

UNCTAD secretariat, 1999, Ports newsletter No 19, https://unctad.org/en/Docs/posdtetibm15.en.pdf [20.04.2020].

WISA - Water Innovation System Amplifier, https://southbaltic.eu/-/wisa [22.04.2020].

Zarząd Morskiego Portu Gdynia S.A., https://www.port. gdynia.pl [21.04.2020]. 